Review

\title{
Clinical Significance of Occult Hepatitis B Infection in Progression of Liver Disease and Carcinogenesis
}

\author{
Hiroki Nishikawa ${ }^{\varpi}$, Yukio Osaki \\ Department of Gastroenterology and Hepatology, Osaka Red Cross Hospital, Osaka, Japan \\ $\triangle$ Corresponding author: Hiroki Nishikawa, Department of Gastroenterology and Hepatology, Osaka Red Cross Hospital, 5-30 Fudegasa- \\ ki-cho, Tennoji-ku, Osaka 543-0027, Japan. Tel: +81-6-6774-5111; Fax: +81-6-6774-5131. E-mail: h-nishikawa@osaka-med.jrc.or.jp \\ (c) Ivyspring International Publisher. This is an open-access article distributed under the terms of the Creative Commons License (http://creativecommons.org/ \\ licenses/by-nc-nd/3.0/). Reproduction is permitted for personal, noncommercial use, provided that the article is in whole, unmodified, and properly cited.
}

Received: 2013.05.03; Accepted: 2013.07.05; Published: 20I3.07.II

\begin{abstract}
Occult hepatitis $B$ infection $(O B I)$ is defined as long-lasting persistence of hepatitis $B$ virus (HBV) DNA in the liver of patients with hepatitis $B$ surface antigen ( $\mathrm{HBs} A g)$-negative status, with or without serological markers of previous exposure (antibodies to $\mathrm{HBsAg}$ and/or to hepatitis $\mathrm{B}$ core antigen). Over the past two decades, significant progress has been made in understanding $O B I$ and its clinical implications. $\mathrm{OBI}$ as a cause of chronic liver disease in patients with $\mathrm{HBsAg-negative}$ status is becoming an important disease entity. In conditions of immunocompetence, $\mathrm{OBI}$ is inoffensive in itself and detection of HBV DNA in the liver does not always indicate active hepatitis. However, when other factors that cause liver damage, such as hepatitis $C$ virus infection, obesity and alcohol abuse are present, the minimal lesions produced by the immunological response to $\mathrm{OBI}$ might worsen the clinical course of the underlying liver disease. Several lines of evidence suggest that $\mathrm{OBI}$ is associated with progression of liver fibrosis and the development of hepatocellular carcinoma in patients with chronic liver disease. The major interest in OBI is primarily associated with the growing, widely discussed evidence of its clinical impact. The aim of this review is to highlight recent data for $\mathrm{OBI}$, with a major focus on disease progression or carcinogenesis in patients with chronic liver disease.
\end{abstract}

Key words: hepatitis B virus, occult hepatitis B infection, chronic liver disease, carcinogenesis, clinical outcome

\section{Introduction}

Hepatitis B virus (HBV) belongs to a family of closely related DNA viruses called the hepadnaviruses and it contains a $3.2-\mathrm{kb}$ partially double-stranded DNA genome with four open reading frames encoding seven proteins. ${ }^{1} \mathrm{HBV}$ is a major causative agent of hepatocellular carcinoma (HCC) and it remains a major public health problem worldwide. ${ }^{2}$ Up to 400 million people worldwide have hepatitis B surface antigen (HBsAg)-positive chronic viral infection, which is primarily acquired by vertical transmission in high-endemicity countries. However, in individuals with low HBV viral load, HBV may not be detectable by commonly used serological assays based on detection of HBsAg and this unapparent infection makes the true incidence of HBV infection difficult to estimate. Thus, the pathogenic importance of HBV infection may be greater than that presently assumed. ${ }^{3,4}$ During the natural history of chronic hepatitis $\mathrm{B}$, seroconversion from HBsAg to anti-HB surface antibody (anti-HBs) is related to the remission of active hepatitis and improvement of liver function and pathological features. Individuals who have recovered from acute hepatitis B or those who have lost serum HBsAg during their clinical course might carry HBV genomes for several years without presenting any clinical evidence of chronic liver disease. ${ }^{5-7}$

In a small proportion of individuals, detectable HBV DNA in the serum and/or the liver is observed 
in the absence of circulating HBsAg. ${ }^{8-11}$ Occult hepatitis $B$ infection (OBI) is defined by the presence of HBV DNA in the liver tissue of individuals who test negative for $\mathrm{HBsAg}$, regardless of the detection of HBV DNA in serum. ${ }^{8}$ OBI was first reported in the 1980s when hybridization techniques for the detection of HBV DNA became available. ${ }^{12}$ Prevalence of OBI has been demonstrated to be associated with the overall prevalence of $\mathrm{HBV}$ infection in a given country (i.e., individuals from countries highly endemic for HBV are more likely to develop OBI). ${ }^{13}$ Prevalence is higher in seropositive patients, particularly those who are positive for antibody to $\mathrm{HB}$ core antigen (anti-HBc), than in seronegative patients who are negative for anti-HBc as well as anti-HBs. ${ }^{9,14}$ Anti-HBc positivity is thus reported to be a surrogate marker for such latent HBV carriers. ${ }^{15} \mathrm{OBI}$ is observed in up to $30 \%$ of serum samples and $50 \%$ of liver biopsies of patients with chronic hepatitis $\mathrm{C}$ virus (HCV) infection. $7,14-17$

The clinical implications of OBI involve different clinical contexts as follows: (1) harboring potential risk of $\mathrm{HBV}$ transmission through hemodialysis, blood transfusion, and organ transplantation; (2) causing cryptogenic liver disease; (3) contributing to the progression of liver disease or even HCC; and (4) affecting response to antiviral therapy for patients with chronic HCV infection. ${ }^{18-21}$ Thus, OBI as a cause of chronic liver disease in patients with HBsAg-negative status is becoming an important disease entity. 10,14,21,22 Despite its potential clinical significance, knowledge of the effect of $\mathrm{OBI}$ in patients with chronic liver disease is limited because HBV-DNA detection may require liver tissue, and liver biopsies are not routinely performed in the majority of such patients in clinical settings. In addition, most previous studies addressing this issue have in- cluded small sample sizes or heterogeneous populations, or are cross-sectional, and the use of different methods with variable sensitivity for HBV-DNA determination in the liver or serum may explain the discrepancies in the influence of OBI in patients with chronic liver disease. ${ }^{23-26}$ The aim of the current review is to highlight recent evidence of OBI with a focus on its progression or carcinogenesis in patients with chronic liver disease.

\section{Definition of OBI}

Chronic HBV infection is defined by the persistence of serum HBsAg for $>6$ months. The gold standard for diagnosis of OBI is analysis of HBV-DNA extracts from the liver and blood samples. ${ }^{11,27}$ However, extracted liver samples are only available in a minority of cases, therefore, diagnosis of OBI is most often based on analysis of serum samples. ${ }^{9}$ In general, OBI is defined by the presence of HBV DNA in the liver tissue of individuals who test negative for HBsAg, regardless of the detection of HBV DNA in the serum. Highly sensitive commercial assays should be preferred for HBsAg and HBV-DNA testing. When HBV DNA is detectable, its level in the serum is usually low $(<200 \mathrm{IU} / \mathrm{mL}$ ). Depending on the HBV antibodies detected, OBI may be seronegative (anti-HBc and anti-HBs negative) or seropositive (anti-HBc and/or anti-HBs positive). ${ }^{9}$ More than $20 \%$ of individuals with OBI have no seropositive markers. ${ }^{8,14}$ In addition, viral replication appears to be regulated by different mechanisms: for patients with anti-HBc positivity, by a T-cell response of protective memory; whereas anti-HBc-negative patients have no HBV-specific T-cell expansion, indicating that persistent low HBV-DNA infection is insufficient for protective memory to mature (Figure 1 ). ${ }^{28}$

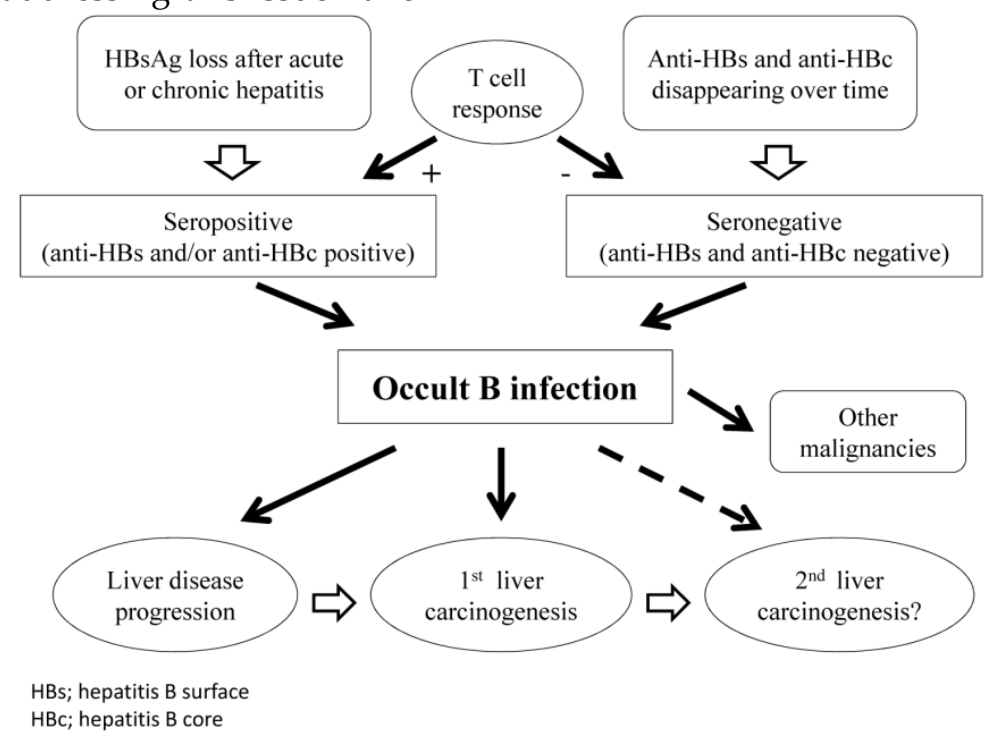

Figure I. Schematic representation of clinical course in patients with OBI. 


\section{OBI and Chronic HCV Infection: Effect on Progression of Liver Fibrosis}

$\mathrm{HBV}$ and HCV share common routes of transmission and this explains the high prevalence of OBI reported in patients with HCV.8,14,29,30 Selim et al. reported that in 60 HBsAg-negative patients with chronic HCV infection, HBV DNA was detected in four $(13.3 \%)$ of 30 patients with normal or slightly high alanine aminotransferase (ALT) levels. ${ }^{31}$ However, in those with ALT flare $(n=30)$, HBV DNA was detected in $19(63.3 \%)$ patients $(P<0.001){ }^{31}$ This indicates that in patients with $\mathrm{HCV}, \mathrm{OBI}$ may contribute to increased plasma HCV RNA loads and liver transaminase levels. Cacciola et al. reported that 66 $(33 \%)$ of 200 patients with chronic HCV infection had HBV genomes, as did seven (14\%) of 50 patients with liver disease unrelated to $\mathrm{HCV}(P=0.01) .{ }^{29}$ Among these 66 patients with $\mathrm{HCV}$ who had HBV genomes, 46 were anti-HBc positive and 20 were negative for all HBV markers $(P<0.001) .{ }^{29}$ Twenty-two $(33 \%)$ of these 66 patients had liver cirrhosis, as compared with 26 $(19 \%)$ of the 134 patients with HCV infection but no HBV sequences $(P=0.04) .{ }^{29}$ This suggests that patients with chronic $\mathrm{HCV}$ infection and OBI more frequently have liver cirrhosis than those with chronic $\mathrm{HCV}$ infection alone. ${ }^{29}$ Likewise, Matsuoka et al. demonstrated that in patients with chronic HCV infection, the mean score of fibrosis stage and degree of inflammatory cell infiltration in patients with OBI were significantly greater than in those without OBI. ${ }^{32}$ Furthermore, Ikeda, et al. found that $251(43.6 \%)$ of 576 patients with chronic HCV infection had anti-HBc positivity, which is a surrogate marker for OBI, while $141(52.2 \%)$ of 270 patients with HCV-related liver cirrhosis had anti-HBc positivity. ${ }^{16}$ They concluded that the proportion of patients with chronic HCV infection with OBI increases in association with progression of liver fibrosis. 16

However, these observations have not been confirmed by other investigations. Kao et al. reported that in patients with chronic HCV infection, the prevalence of OBI did not parallel the severity of liver disease. ${ }^{33}$ OBI was seen in $16(14.5 \%)$ of 110 patients with chronic hepatitis, four $(8 \%)$ of 50 patients with liver cirrhosis, and $11(22 \%)$ of 50 patients with HCC. 33 They concluded that OBI does not have clinical significance in patients with chronic $\mathrm{HCV}$ infection. ${ }^{33}$ Hui et al. examined a retrospective cohort of 74 HCV-infected patients and reported that 11 (35.5\%) of 31 with OBI compared with $12(27.9 \%)$ of 43 without OBI had fibrosis progression $(P=0.608) \cdot{ }^{34}$ Also, six $(19.4 \%)$ of 31 patients with OBI compared with eight (18.6\%) of 43 without OBI developed severe fibrosis $(P$ $=0.946) \cdot{ }^{34}$ They concluded that patients with chronic
$\mathrm{HCV}$ infection with OBI do not seem to progress more than patients without OBI. ${ }^{34}$ Similarly, Sagnelli et al. studied 89 patients [37 $(41.6 \%)$ with OBI] with biopsy-proven chronic HCV infection and reported that there was no significant association between OBI and degree of liver necroinflammation and fibrosis. ${ }^{23}$

The predominance of certain HBV genotypes in patients with chronic $\mathrm{HCV}$ infection and OBI, and their potential role in determining clinical outcome, has been reported recently. ${ }^{35}$ The authors suggest that genotype B or D may influence the outcome of OBI, which may lead to progression of liver disease. ${ }^{35} \mathrm{In}$ terms of HCV genotypes, a higher proportion of OBI was detected in patients with HCV genotype $1 b$ than in those with genotype $2 \mathrm{a} .{ }^{36}$

In view of previous reports, results of the combined effect of chronic $\mathrm{HCV}$ infection and OBI on progression of liver disease have yielded controversial results and no firm conclusion can be reached.

\section{Mechanism of Carcinogenesis in Patients with OBI}

The direct mechanism of carcinogenesis in HBV-related HCC includes mutagenesis and changes in proliferation and differentiation caused by integration of HBV DNA into the host genome (HCV is an RNA virus, therefore, it is not integrated into host hepatocyte DNA, which causes the mutation). ${ }^{37,38}$ OBI may maintain these direct mechanisms of HBV-related carcinogenesis, such as the ability to be integrated into the host genome and production of transforming proteins, mainly including $\mathrm{X}$ and preS-S proteins.11,32,39-41 In contrast, OBI may also exert pro-oncogenic properties through indirect mechanisms. These are associated with its propensity to induce persistent necroinflammation in the liver and to promote progression of chronic hepatitis to liver cirrhosis, which indicates the step preceding HCC occurrence in the majority of cases.11,20-22,25,26,41 Furthermore, indirectly, continuous HBV replication caused by OBI can mediate alterations in transforming growth factor- $\beta 1$ and $\alpha 2$-macrogloblin production, leading to liver carcinogenesis. ${ }^{42}$

\section{Effect of OBI on Risk of HCC Develop- ment in Patients with Chronic HCV In- fection}

The risk of HCC development has been reported to increase up to 100 -fold in patients with chronic HBV infection. ${ }^{11,43}$ Chronic infection with HBV or $\mathrm{HCV}$ is the major cause of HCC worldwide. ${ }^{2}$ Central questions include the influence of OBI on liver carcinogenesis in patients with HCV-related liver disease. 
Ikeda et al. demonstrated in a multicenter prospective study that in patients with HCV-related liver cirrhosis $(n=270)$, HCC developed in $85(60.3 \%)$ of 141 patients with anti-HBc and $58(45.0 \%)$ of 129 patients without anti-HBc. ${ }^{16}$ Their multivariate analysis of factors contributing to HCC occurrence identified that anti-HBc positivity was an independent risk factor with a hazard ratio (HR) of $1.58 .{ }^{16}$ Similarly, Adachi et al. reported in a prospective study of 123 patients with HCV-related liver cirrhosis that cumulative 5-year HCC development rates were $59.2 \%$ in the anti-HBc-positive group $(n=96)$ and $37.8 \%$ in the anti-HBc-negative group $(n=27)(P=0.0039) .{ }^{24}$ Their multivariate analysis identified that anti-HBc positivity was a significant adverse predictor linked to development of HCC with an HR of $3.111(P=0.001) .{ }^{24}$ They concluded that serum anti-HBc positivity, namely potential $\mathrm{OBI}$, has clinical significance in hepatocarcinogenesis in patients with $\mathrm{HCV}$-related liver cirrhosis. ${ }^{24}$ In another large prospective study, Matsuoka et al. prospectively studied the effect of OBI on the histopathological features and clinical outcomes of 468 patients with HBsAg-negative chronic $\mathrm{HCV}$ infection. ${ }^{32}$ They demonstrated that the cumulative probability of development of HCC was significantly higher for HBV-DNA-positive patients than for HBV-DNA-negative patients, and that HBV-DNA positivity was an independent risk factor for the occurrence of HCC. ${ }^{32}$ Miura et al. investigated the influence of OBI, focusing on HCC development in patients in whom HCV eradication by interferon therapy had failed. ${ }^{44}$ Their multivariate analysis revealed that low platelet count, OBI, high ALT levels after interferon therapy, and liver fibrosis stage were important independent factors associated with HCC development. ${ }^{44}$ They concluded that OBI is a risk factor for HCC development in patients with chronic $\mathrm{HCV}$ infection in whom HCV eradication has failed. ${ }^{44}$
Obika et al. suggested in a prospective study that a high amount of HBV DNA in liver tissue of HBsAg-negative patients with HCV-related liver disease was associated with HCC development. ${ }^{45}$

In contrast, Anna et al. reported that there was no difference in prevalence of anti-HBc in serum or HBV DNA in liver between patients who did or did not develop HCC. ${ }^{46}$ Anti-HBc was present in the serum of $41.8 \%$ of HCC cases and $45.6 \%$ of controls $(P=$ $0.54)$, and HBV DNA was detected in the liver of $10.7 \%$ of HCC cases and $23.6 \%$ of controls $(P=0.18) .{ }^{46}$ They reached the conclusion that OBI is not an important factor in HCC development among patients with advanced chronic HCV infection. ${ }^{46}$ In addition, Tsubouchi et al. found in a community-based cohort study that there was no significant difference in the incidence of HCC and cumulative mortality associated with liver-related death between $\mathrm{HCV}$ carriers who were positive and those who were negative for anti-HBc. ${ }^{47}$

Recently, Shi et al. conducted a meta-analysis of prospective and retrospective studies to investigate whether OBI increases the risk of HCC. ${ }^{48}$ They demonstrated in 12 eligible studies that $\mathrm{OBI}$ increases the risk for $\mathrm{HCC}$ in $\mathrm{HCV}$-infected populations [risk ratio $(\mathrm{RR})=2.83,95 \%$ confidence interval $(\mathrm{CI})=$ 1.56-4.10]. ${ }^{48}$

In summary, these results suggest that OBI may increase the likelihood of developing HCC in patients with chronic $\mathrm{HCV}$ infection. However, to reach the conclusion that OBI plays a pivotal role in the development of HCC in patients with HCV-related liver disease, further studies on molecular pathogenesis and prospective molecular epidemiological studies will be required. Previous prospective studies evaluating the effect of OBI or potential OBI on liver carcinogenesis in patients with HCV-related liver disease are listed in Table 1.

Table I. Prospective studies evaluating the effect of occult $\mathrm{B}$ infection $(\mathrm{OBI})$ or potential $\mathrm{OBI}$ on carcinogenesis in patients with chronic hepatitis $C$.

\begin{tabular}{lllllll}
\hline Author & Country & Year & Study design & $\begin{array}{l}\text { No. of } \\
\text { patients }\end{array}$ & $\begin{array}{l}\text { No. of HCC occurrence / OBI or No. of HCC occurrence / OBI or } \\
\text { potential OBI positive patients } \\
(\%)\end{array}$ & $\begin{array}{l}\text { potential OBI negative patients (\%) } \\
\text { pots }\end{array}$ \\
\hline Hasegawa, et al $^{18}$ & Japan & 2005 & Prospective & 140 & $2 / 11(18.2 \%)$ & $16 / 129(12.4 \%)^{* *}$ \\
Squadrito, et al $^{39}$ & Italy & 2006 & Prospective & 124 & $8 / 50(16.0 \%)$ & $1 / 74(1.4 \%)^{*}$ \\
Ikeda, et al $^{16}$ & Japan & 2007 & Prospective & 846 & $130 / 392(33.2 \%)$ & $107 / 454(23.6 \%)^{*}$ \\
Matsuoka, et al $^{32}$ & Japan & 2008 & Prospective & 468 & $29 / 204(14.2 \%)$ & $9 / 264(3.4 \%)^{*}$ \\
Obika, et al ${ }^{45}$ & Japan & 2008 & Prospective & 167 & $2 / 25(8.0 \%)$ & $10 / 142(7.0 \%)^{* *}$ \\
Anna, et al ${ }^{46}$ & USA & 2011 & Prospective & 273 & $38 / 121(31.4 \%)$ & $53 / 152(34.9 \%)^{* *}$ \\
\hline
\end{tabular}

HCC; hepatocelluar carcinoma, ${ }^{*}$; statistically significant, ${ }^{* *}$; statistically not significant 


\section{Influence of OBI on Carcinogenesis in Patients with Cryptogenic Liver Disease}

OBI can be detected in patients with cryptogenic chronic liver disease and may be related to the progression of liver fibrosis. ${ }^{49-51}$ However, specific guidelines for the management of OBI-related liver disease are yet to evolve. OBI has also been demonstrated in patients with autoimmune hepatitis and nonalcoholic steatohepatitis. ${ }^{52,53}$ The frequency of OBI in patients with cryptogenic liver cirrhosis has ranged from $4.8 \%$ to $40 \%$ in previous studies, depending on the prevalence of HBV and the type of specimen examined (liver or serum). ${ }^{54-56}$ Interestingly, a previous study has suggested that HBV DNA is integrated into the human genome in non-B and non-C (NBNC) HCC tissues, indicating that $\mathrm{OBI}$ might play a role in hepatocarcinogenesis in patients with NBNC liver disease. ${ }^{57} \mathrm{OBI}$ has thus a negligible role in the pathogenesis of cryptogenic chronic liver disease.

Ikeda et al. reported that in 82 patients with NBNC liver cirrhosis, the presence of $\mathrm{HBc}$ and $\mathrm{HBx}$ DNA, which is a transactivator of viral regulatory elements and host gene promoters with a potential role in carcinogenesis, was an independent factor associated with liver carcinogenesis $(\mathrm{RR}=8.25, P=$ 0.003). ${ }^{17,58,59}$ Yotsuyanagi et al. studied HBV DNA in serum and liver tissues in 42 patients with NBNC HCC and reported that HBV DNA was detected in the sera of $20(47.6 \%)$. This was significantly higher than in age-matched controls without liver disease $(P<$ 0.001 ), suggesting that HBV is associated with a substantial proportion of NBNC HCC cases. ${ }^{60}$ In contrast, Kusakabe et al. found a weak association between OBI and HCC development in patients with NBNC liver disease. ${ }^{61}$ Furthermore, Shi et al. demonstrated in a meta-analysis of four eligible studies that OBI increased the risk of HCC development with an HR of 10.65 (95\% CI $=5.94-10.98)$ in patients with chronic liver disease unrelated to hepatitis virus. ${ }^{48}$

Overall, OBI may play a significant role in promoting tumor growth unrelated to hepatitis virus. In patients with hepatitis-unrelated chronic liver disease, the risk of HCC might be entirely attributed to OBI; however, further studies will be needed to confirm these hypotheses.

\section{Effect of OBI on Survival in Patients with HCC Who Underwent Curative Therapy}

HCC is diagnosed in more than half a million people worldwide each year, and therefore it is a major global health problem. HCC is the fifth most common cancer in the world and the third most common cause of cancer-related death. ${ }^{62-64} \mathrm{HCC}$ often recurs. The prognosis of HCC is generally poor because of a high post-treatment recurrence rate. Recurrence only occurs at intrahepatic sites in $68-96 \%$ of patients. The identification of prognostic factors for HCC recurrence is thus essential for improving survival, even after curative treatment. ${ }^{2,65-67}$ The pathogenesis of HCC recurrence has been extensively examined and various risk factors associated with HCC recurrence have been identified. ${ }^{68-70}$ However, whether potential OBI can be a risk factor linked to HCC recurrence after curative therapy for HCC remains elusive.

Kubo et al. examined the effect of anti-HBc positivity on survival in 59 patients who underwent liver resection for HCV-related HCC $(<2.0 \mathrm{~cm}$ in greatest dimension). ${ }^{71}$ Tumor-free survival tended to be lower in patients with anti-HBc positivity than in those without anti-HBc positivity $(P=0.0758) .{ }^{71}$ The cumulative survival rate was significantly lower in patients with anti-HBc positivity than in those without anti-HBc positivity $(P=0.0224)$, with an RR of anti-HBc for shorter survival of $3.817 . .^{71} \mathrm{We}$ also analyzed the influence of anti-HBc positivity on survival in 222 patients with HCV-related, HBsAg-negative HCC who underwent curative surgical resection [119 anti-HBc-positive patients $(53.6 \%)$ and 103 anti-HBc-negative patients (46.4\%)]. ${ }^{72}$ The 3-year cumulative overall survival rate was $70.2 \%$ in the anti-HBc-positive group and $77.1 \%$ in the anti-HBc-negative group $(P=0.300)$. The corresponding recurrence-free survival rates were $33.0 \%$ in the anti-HBc-positive group and $38.5 \%$ in the anti-HBc-negative group $(P=0.482) .{ }^{72} \mathrm{We}$ thus concluded that anti-HBc positivity cannot be a useful predictor for survival in patients with $\mathrm{HCV}$-related HCC after curative surgery. ${ }^{72}$ Whether anti-HBc positivity constitutes an additional risk in terms of survival after curative therapy for HCV-related HCC therefore appears to be controversial.

In patients with NBNC HCC who undergo curative therapy, it is also unclear whether anti-HBc positivity is a predictor for survival. In our single-center experience, in 260 patients with NBNC HCC who underwent curative therapy [124 anti-HBc-positive patients $(47.7 \%)$ and 136 anti-HBc-negative patients $(52.3 \%)]$, the 1-, 3-, and 5-year recurrence-free survival rates were $65.1,29.8$, and $14.0 \%$, respectively, in the anti-HBc-positive group and $78.9,43.0$, and $36.7 \%$ in the anti-HBc-negative group $(P=0.001) .{ }^{49}$ By multivariate analysis, anti-HBc positivity was an independent predictor linked to HCC recurrence with an HR of $1.567(P=0.006) .{ }^{49}$ Anti-HBc positivity may be a useful predictor for recurrence in patients with NBNC HCC after curative therapy; however, because there have been few reports regarding the effect of OBI on 
survival in patients with hepatitis-unrelated HCC, further studies will be needed.

\section{OBI and Risk of Other Malignancies}

OBI has been reported as a potential risk factor for the development of other malignancies. Wang et al. conducted a meta-analysis involving 5883 patients with pancreatic cancer. ${ }^{73}$ They demonstrated that the RR for development of pancreatic cancer was 1.76 (95\% CI $=1.05-2.93)$ in anti-HBc-positive but anti-HBs-negative individuals, and concluded that OBI may increase the risk of pancreatic cancer. ${ }^{73}$ In patients with hematological malignancies, the presence of OBI cannot be ignored because HBV reactivation may occur in patients with OBI undergoing immunosuppressive therapy or chemotherapy, where it is often associated with the fulminant course of hepatitis, as well as in those with HBsAg positivity. ${ }^{4,9,11}$ Liu et al. found in 405 patients with non-Hodgkin lymphoma that the positive rate of anti-HBc was $47.9 \%$, which was significantly different from that in the general population $(P<0.01) \cdot{ }^{74}$ Furthermore, Rossi et al. examined the prevalence of OBI in 173 patients with chronic lymphocytic leukemia. ${ }^{75}$ OBI was observed in 17/173 (10\%) patients and 5/173 (3\%) ageand sex-matched controls $(\mathrm{RR}=3.6,95 \% \mathrm{CI}=$ 1.37-9.79, $P=0.014)$. The tumorigenic mechanisms caused by OBI need to be elucidated. ${ }^{75}$ Clinicians should also be alert to the presence of OBI in patients with other malignancies.

\section{Conclusions}

OBI is a complex disease entity comprising different situations. The definition of OBI should be based on high-sensitivity HBsAg and HBV-DNA testing. The cumulative evidence has revealed its possible implication in various clinical contexts. The oncogenic potential of OBI has become progressively evident. OBI may exert oncogenic activity through direct and indirect mechanisms, and it can affect liver disease progression and hepatocarcinogenesis in patients with other viral causes, particularly $\mathrm{HCV}$, as well as in those with hepatitis-unrelated liver disease. Whether OBI is associated with secondary carcinogenesis in HCC patients after curative therapy remains unclear. Further studies examining this issue should be conducted in the future. OBI may be a potential risk factor for development of other cancers.

\section{Acknowledgments}

The authors would like to thank all the staff in their hospital for their valuable support.

\section{Competing Interests}

The authors have not received any financial support for this article and have no conflicts of interest to declare.

\section{References}

1. Lee WM. Hepatitis B virus infection. N Engl J Med. 1997; 337(24): 1733-45.

2. El-Serag HB. Hepatocellular carcinoma. N Engl J Med. 2011 Sep 22; 365(12): 1118-27.

3. Lok AS, McMahon BJ; Practice Guidelines Committee, American Association for the Study of Liver Diseases. Chronic hepatitis B. Hepatology. 2001; 34(6): 1225-41.

4. Mulrooney-Cousins PM, Michalak TI. Persistent occult hepatitis B virus infection: experimental findings and clinical implications. World J Gastroenterol. 2007; 13(43): 5682-6.

5. Michalak TI, Pasquinelli C, Guilhot S, Chisari FV. Hepatitis B virus persistence after recovery from acute viral hepatitis. J Clin Invest. 1994; 93(1): 230-9.

6. Yotsuyanagi H, Yasuda K, Iino S, Moriya K, Shintani Y, Fujie H, Tsutsumi T, Kimura S, Koike K. Persistent viremia after recovery from self-limited acute hepatitis B. Hepatology. 1998; 27(5): 1377-82.

7. Wong DK, Huang FY, Lai CL, Poon RT, Seto WK, Fung J, Hung IF, Yuen MF. Occult hepatitis B infection and HBV repli-cative activity in patients with cryptogenic cause of hepatocellular carcinoma. Hepatology. 2011; 54: 829-836.

8. Raimondo G, Pollicino T, Cacciola I, Squadrito G. Occult hepatitis B virus infection. J Hepatol. 2007; 46: 160-170.

9. Raimondo G, Allain JP, Brunetto MR, Buendia MA, Chen DS, Colombo M, Craxì A, Donato F, Ferrari C, Gaeta GB, Gerlich WH, Levrero M, Locarnini S, Michalak T, Mondelli MU, Pawlotsky JM, Pollicino T, Prati D, Puoti M, Samuel D, Shouval D, Smedile A, Squadrito G, Trépo C, Villa E, Will H, Zanetti AR, Zoulim F. Statements from the Taormina expert meeting on occult hepatitis B virus infection. J Hepatol. 2008; 49: 652-657.

10. Bréchot C, Thiers V, Kremsdorf D, Nalpas B, Pol S, Paterlini-Bréchot P. Persistent hepatitis B virus infection in subjects without hepatitis B surface antigen: clinically significant or purely "occult"? Hepatology 2001; 34: 194-203.

11. Samal J, Kandpal M, Vivekanandan P. Molecular mechanisms underlying occult hepatitis B virus infection. Clin Microbiol Rev. 2012; 25(1): 142-63.

12. C. Brechot, F. Degos, C. Lugassy, V. Thiers, S. Zafrani, D. Franco, H. Bismuth, C. Trepo, J.P. Benhamou, J. Wands, K. Isselbacher, P. Tiollais, P. Berthelot. Hepatitis B virus DNA in patients with chronic liver disease and negative tests for hepatitis B surface antigen. N Engl J Med. 1985; 312: $270-276$

13. Marrero JA, Lok AS. Occult hepatitis B virus infection in patients with hepatocellular carcinoma: Innocent bystander, cofactor, or culprit? Gastroenterology. 2004; 126(1): 347-50.

14. Torbenson M, Thomas DL. Occult hepatitis B. Lancet Infect Dis. 2002; 2: $479-486$.

15. Jilg W, Sieger E, Zachoval R, Schätzl H. Individuals with antibodies against hepatitis $B$ core antigen as the only serological marker for hepatitis B infection: high percentage of carriers of hepatitis B and C virus. J Hepatol. 1995; 23(1): 14-20.

16. Ikeda K, Marusawa H, Osaki Y, Nakamura T, Kitajima N, Yamashita Y, Kudo M, Sato T, Chiba T. Antibody to hepatitis B core antigen and risk for hepatitis C-related hepatocellular carcinoma: a prospective study. Ann Intern Med. 2007; 146: 649-656.

17. Ikeda K, Kobayashi M, Someya T, Saitoh S, Hosaka T, Akuta N, Suzuki F, Suzuki Y, Arase Y, Kumada H. Occult hepatitis B virus infection increases hepatocellular carcinogenesis by eight times in patients with non-B, non-C liver cirrhosis: a cohort study. J Viral Hepat. 2009; 16(6): 437-43.

18. Hasegawa I, Orito E, Tanaka Y, Hirashima N, Sakakibara K, Sakurai M, Suzuki S, Sugauchi F, Ohno T, Ueda R, Mizokami M. Impact of occult hepatitis $\mathrm{B}$ virus infection on efficacy and prognosis of interferon-alpha therapy for patients with chronic hepatitis C. Liver Int. 2005; 25: 247-253.

19. Levast M, Larrat S, Thelu MA, Nicod S, Plages A, Cheveau A, Zarski JP, Seigneurin JM, Morand P, Leroy V. Prevalence and impact of occult hepatitis B infection in chronic hepatitis C patients treated with pegylated interferon and ribavirin. J Med Virol. 2010; 82: 747-754.

20. Raimondo G, Caccamo G, Filomia R, Pollicino T. Occult HBV infection. Semin Immunopathol. 2013; 35(1): 39-52.

21. Covolo L, Pollicino T, Raimondo G, Donato F. Occult hepatitis B virus and the risk for chronic liver disease: a meta-analysis. Dig Liver Dis. 2013; 45(3): 238-44. 
22. De Mitri MS, Cassini R, Bernardi M. Hepatitis B virus-related hepatocarcinogenesis: molecular oncogenic potential of clear or occult infections. Eur J Cancer 2010; 46: 2178-2186.

23. Sagnelli E, Imparato M, Coppola N, Pisapia R, Sagnelli C, Messina V, Piai G, Stanzione M, Bruno M, Moggio G, Caprio N, Pasquale G, Del Vecchio Blanco C. Diagnosis and clinical impact of occult hepatitis B infection in patients with biopsy proven chronic hepatitis $\mathrm{C}$ : a multicenter study. J Med Virol. 2008; 80: 1547-1553.

24. Adachi S, Shibuya A, Miura Y, Takeuchi A, Nakazawa T, Saigenji K. Impact of occult hepatitis B virus infection and prior hepatitis B virus infection on development of hepatocellular carcinoma in patients with liver cirrhosis due to hepatitis C virus. Scand J Gastroenterol. 2008; 43: 849-856.

25. Alavian SM, Miri SM, Hollinger FB, Jazayeri SM. Occult Hepatitis B $(\mathrm{OBH})$ in Clinical Settings. Hepat Mon. 2012; 12(8): e6126.

26. Zobeiri M. Occult hepatitis B: clinical viewpoint and management. Hepat Res Treat. 2013; 2013: 259148.

27. Lai CL, Yuen MF. Prevention of hepatitis B virus-related hepatocellular carcinoma with antiviral therapy. Hepatology. 2013; 57(1): 399-408.

28. Zerbini A, Pilli M, Boni C, Fisicaro P, Penna A, Di Vincenzo P, Giuberti T, Orlandini A, Raffa G, Pollicino T, Raimondo G, Ferrari C, Missale G. The characteristics of the cell-mediated immune response identify different profiles of occult hepatitis B virus infection. Gastroenterology. 2008; 134(5): 1470-81.

29. Cacciola I, Pollicino T, Squadrito G, Cerenzia G, Orlando ME, Raimondo G. Occult hepatitis B virus infection in patients with chronic hepatitis C liver disease. N Engl J Med. 1999; 341: 22-26.

30. Chemin I, Trépo C. Clinical impact of occult HBV infections. J Clin Virol. 2005; 34 Suppl 1: S15-S21.

31. Selim HS, Abou-Donia HA, Taha HA, El Azab GI, Bakry AF. Role of occult hepatitis B virus in chronic hepatitis $C$ patients with flare of liver enzymes. Eur J Intern Med. 2011; 22(2): 187-90.

32. Matsuoka S, Nirei K, Tamura A, Nakamura H, Matsumura H, Oshiro S, Arakawa Y, Yamagami H, Tanaka N, Moriyama M. Influence of occult hepatitis $B$ virus coinfection on the incidence of fibrosis and hepatocellular carcinoma in chronic hepatitis C. Intervirology. 2008; 51: 352-36.

33. Kao JH, Chen PJ, Lai MY, Chen DS. Occult hepatitis B virus infection and clinical outcomes of patients with chronic hepatitis C. J Clin Microbiol. 2002; 40(11): 4068-71.

34. Hui CK, Lau E, Wu H, Monto A, Kim M, Luk JM, Lau GK, Wright TL. Fibrosis progression in chronic hepatitis $\mathrm{C}$ patients with occult hepatitis B co-infection. J Clin Virol. 2006; 35: 185-192.

35. Hassan ZK, Hafez MM, Mansor TM, Zekri AR. Occult HBV infection among Egyptian hepatocellular carcinoma patients. Virol J. 2011; 8: 90.

36. Fukuda R, Ishimura N, Niigaki $M$, Hamamoto $S$, Satoh $S$, Tanaka $S$, Kushiyama Y, Uchida Y, Ihihara S, Akagi S, Watanabe M, Kinoshita Y. Serologically silent hepatitis B virus coinfection in patients with hepatitis $\mathrm{C}$ virus-associated chronic liver disease: clinical and virological significance. J Med Virol. 1999; 58(3): 201-7.

37. Kim CM, Koike K, Saito I, Miyamura T, Jay G. HBx gene of hepatitis B virus induces liver cancer in transgenic mice. Nature. 1991; 351(6324): 317-20.

38. Tamori A, Yamanishi Y, Kawashima S, Kanehisa M, Enomoto M, Tanaka $\mathrm{H}$, Kubo S, Shiomi S, Nishiguchi S. Alteration of gene expression in human hepatocellular carcinoma with integrated hepatitis B virus DNA. Clin Cancer Res. 2005; 11(16): 5821-6.

39. Squadrito G, Pollicino T, Cacciola I, Caccamo G, Villari D, La Masa T, Restuccia T, Cucinotta E, Scisca C, Magazzu D, Raimondo G. Occult hepatitis $\mathrm{B}$ virus infection is associated with the development of hepatocellular carcinoma in chronic hepatitis C patients. Cancer. 2006; 106(6): 1326-30.

40. Pollicino T, Squadrito G, Cerenzia G, Cacciola I, Raffa G, Craxi A, Farinati F, Missale G, Smedile A, Tiribelli C, Villa E, Raimondo G. Hepatitis B virus maintains its pro-oncogenic properties in the case of occult $\mathrm{HBV}$ infection. Gastroenterology. 2004; 126(1): 102-10.

41. Arababadi MK, Nasiri Ahmadabadi B, Kennedy D. Current information on the immunologic status of occult hepatitis B infection. Transfusion. 2012; 52(8): 1819-26.

42. Pan J, Clayton M, Feitelson MA. Hepatitis B virus $X$ antigen promotes transforming growth factor-beta1 (TGF-beta1) activity by up-regulation of TGF-beta1 and down-regulation of alpha2-macroglobulin. J Gen Virol. 2004; 85(Pt 2): 275-82

43. Wright TL, Lau JY. Clinical aspects of hepatitis B virus infection. Lancet. 1993; 342(8883): 1340-4.

44. Miura Y, Shibuya A, Adachi S, Takeuchi A, Tsuchihashi T, Nakazawa $\mathrm{T}$, Saigenji K. Occult hepatitis B virus infection as a risk factor for hepatocellular carcinoma in patients with chronic hepatitis $C$ in whom viral eradication fails. Hepatol Res. 2008; 38: 546-556.
45. Obika M, Shinji T, Fujioka S, Terada R, Ryuko H, Lwin AA, Shiraha H, Koide N. Hepatitis B virus DNA in liver tissue and risk for hepatocarcinogenesis in patients with hepatitis $\mathrm{C}$ virus-related chronic liver disease. A prospective study. Intervirology. 2008; 51(1): 59-68.

46. Lok AS, Everhart JE, Di Bisceglie AM, Kim HY, Hussain M, Morgan TR; HALT-C Trial Group. Occult and previous hepatitis B virus infection are not associated with hepatocellular carcinoma in United States patients with chronic hepatitis C. Hepatology. 2011; 54(2): 434-42.

47. Tsubouchi N, Uto H, Kumagai K, Sasaki F, Kanmura S, Numata M, Moriuchi A, Oketani M, Ido A, Hayashi K, Kusumoto K, Shimoda K, Stuver SO, Tsubouchi H. Impact of antibody to hepatitis B core antigen on the clinical course of hepatitis $C$ virus carriers in a hyperendemic area in Japan: A community-based cohort study. Hepatol Res. 2013 [Epub ahead of print]

48. Shi $Y$, Wu YH, Wu W, Zhang WJ, Yang J, Chen Z. Association between occult hepatitis B infection and the risk of hepatocellular carcinoma: a meta-analysis. Liver Int. 2012; 32(2): 231-40.

49. Hiroki Nishikawa, Yukio Osaki, Akira Arimoto, Ryuichi Kita and Toru Kimura. Relation Between Antibody to Hepatitis B Core Antigen and Survival after Curative Therapy for Non-B Non-C Hepatocellular Carcinoma. Anticancer research. 2013. In Press.

50. Fang Y, Shang QL, Liu JY, Li D, Xu WZ, Teng X, Zhao HW, Fu LJ, Zhang FM, Gu HX. Prevalence of occult hepatitis B virus infection among hepatopathy patients and healthy people in China. J Infect. 2009; 58: 383-388.

51. Chemin I, Trépo C. Clinical impact of occult HBV infections. J Clin Virol. 2005; 34 Supp1 1: S15-S21.

52. Honarkar Z, Alavian SM, Samiee S, Saeedfar K, Zali MR. Occult hepatitis B among chronic liver disease patients. Saudi Med J. 2005; 26(4): 601-6.

53. Berasain C, Betés M, Panizo A, Ruiz J, Herrero JI, Civeira MP, Prieto J. Pathological and virological findings in patients with persistent hypertransaminasaemia of unknown aetiology. Gut. 2000; 47(3): 429-35.

54. Hou J, Wang Z, Cheng J, Lin Y, Lau GK, Sun J, Zhou F, Waters J, Karayiannis P, Luo K. Prevalence of naturally occurring surface gene variants of hepatitis $B$ virus in nonimmunized surface antigen-negative Chinese carriers. Hepatology. 2001; 34(5): 1027-34.

55. Brechot C, Thiers V, Kremsdorf D, Nalpas B, Pol S, Paterlini-Brechot P. Persistent hepatitis B virus infection in subjects without hepatitis B surface antigen: clinically significant or purely "occult"? Hepatology. 2001; 34(1): 194-203.

56. Alavian SM, Miri SM, Hollinger FB, Jazayeri SM. Occult Hepatitis B $(\mathrm{OBH})$ in Clinical Settings. Hepat Mon. 2012; 12(8): e6126.

57. Tamori A, Nishiguchi S, Kubo S, Narimatsu T, Habu D, Takeda T, Hirohashi K, Shiomi S. HBV DNA integration and HBV-transcript expression in non-B, non-C hepatocellular carcinoma in Japan. J Med Virol 2003; 71: 492-8.

58. Lu JW, Hsia Y, Yang WY, Lin YI, Li CC, Tsai TF, Chang KW, Shieh GS, Tsai SF, Wang HD, Yuh CH. Identification of the common regulators for hepatocellular carcinoma induced by hepatitis $B$ virus $X$ antigen in a mouse model. Carcinogenesis. 2012; 33(1): 209-19.

59. Wang $C$, Yang W, Yan HX, Luo T, Zhang J, Tang L, Wu FQ, Zhang HL, Yu LX, Zheng LY, Li YQ, Dong W, He YQ, Liu Q, Zou SS, Lin Y, Hu L, Li $\mathrm{Z}$, Wu MC, Wang HY. Hepatitis B virus X (HBx) induces tumorigenicity of hepatic progenitor cells in 3,5-diethoxycarbonyl-1,4dihydrocollidine-treated HBx transgenic mice. Hepatology. 2012; 55(1): 108-20.

60. Yotsuyanagi H, Shintani Y, Moriya K, Fujie H, Tsutsumi T, Kato T, Nishioka K, Takayama T, Makuuchi M, Iino S, Kimura S, Koike K. Virologic analysis of non-B, non-C hepatocellular carcinoma in Japan: frequent involvement of hepatitis B virus. J Infect Dis. 2000; 181(6): 1920-8.

61. Kusakabe A, Tanaka Y, Orito E, Sugauchi F, Kurbanov F, Sakamoto T, Shinkai N, Hirashima N, Hasegawa I, Ohno T, Ueda R, Mizokami M. A weak association between occult HBV infection and non-B non-C hepatocellular carcinoma in Japan. J Gastroenterol. 2007; 42(4): 298-305.

62. Livraghi T, Mäkisalo H, Line PD. Treatment options in hepatocellular carcinoma today. Scand J Surg 2011; 100: 22-29.

63. El-Serag HB. Epidemiology of viral hepatitis and hepatocellular carcinoma. Gastroenterology 2012; 142: 1264-73.

64. de Lope CR, Tremosini S, Forner A, Reig M, Bruix J. Management of HCC. J Hepatol 2012; 56 Suppl 1: S75-S87.

65. Zhou WP, Lai EC, Li AJ, Fu SY, Zhou JP, Pan ZY, Lau WY, Wu MC. A prospective, randomized, controlled trial of preoperative transarterial chemoembolization for resectable large hepatocellular carcinoma. Ann Surgery 2009; 249: 195-202.

66. Nishikawa $\mathrm{H}$, Osaki $\mathrm{Y}$, Kita $\mathrm{R}$, Kimura $\mathrm{T}$, Inuzuka $\mathrm{T}$, Takeda $\mathrm{H}$ Nakajima J, Matsuda F, Sakamoto A, Henmi S, Hatamaru K, Saito S, Nasu A. Transcatheter arterial infusion chemotherapy prior to radiofrequency thermal ablation for single hepatocellular carcinoma reduces the risk of intrahepatic distant recurrence. Int J Oncol 2012; 41: 903-9. 
67. Nishikawa H, Arimoto A, Wakasa T, Kita R, Kimura T, Osaki Y. Effect of transcatheter arterial chemoembolization prior to surgical resection for hepatocellular carcinoma. Int J Oncol. 2013; 42(1): 151-60.

68. Toyoda H, Kumada T, Kaneoka Y, Maeda A. Amino acid substitutions in the hepatitis $C$ virus core region are associated with postoperative recurrence and survival of patients with $\mathrm{HCV}$ genotype $1 \mathrm{~b}$-associated hepatocellular carcinoma. Ann Surg. 2011; 254(2): 326-32.

69. Ikai I, Arii S, Kojiro M, Ichida T, Makuuchi M, Matsuyama Y, Nakanuma Y, Okita K, Omata M, Takayasu K, Yamaoka Y. Reevaluation of prognostic factors for survival after liver resection in patients with hepatocellular carcinoma in a Japanese nationwide survey. Cancer. 2004; 101(4): 796-802.

70. Shiina S, Tateishi R, Arano T, Uchino K, Enooku K, Nakagawa H, Asaoka Y, Sato T, Masuzaki R, Kondo Y, Goto T, Yoshida H, Omata M, Koike K. Radiofrequency ablation for hepatocellular carcinoma: 10-year outcome and prognostic factors. Am J Gastroenterol. 2012; 107(4): 569-77

71. Kubo S, Nishiguchi S, Hirohashi K, Tanaka H, Tsukamoto T, Hamba H, Shuto T, Yamamoto T, Ikebe T, Kinoshita H. Clinical significance of prior hepatitis B virus infection in patients with hepatitis C virus-related hepatocellular carcinoma. Cancer. 1999; 86(5): 793-8.

72. Hiroki Nishikawa, Akira Arimoto, Tomoko Wakasa, Ryuichi Kita, Toru Kimura and Yukio Osaki. Lack of relation between antibody to hepatitis $B$ core antigen and survival after surgical resection for hepatitis-C-virus-related hepatocellular carcinoma. Oncol Rep 2013. [Epub ahead of print]

73. Wang Y, Yang S, Song F, Cao S, Yin X, Xie J, Tu X, Xu J, Xu X, Dong X, Lu $Z$. Hepatitis B virus status and the risk of pancreatic cancer: a meta-analysis. Eur J Cancer Prev. 2012; [Epub ahead of print]

74. Liu WP, Zheng $W$, Wang XP, Song YQ, Xie Y, Tu MF, Lin NJ, Ping LY, Ying ZT, Deng LJ, Zhang C, Zhu J. [An analysis of hepatitis B virus infection rate in 405 cases of non-Hodgkin lymphoma]. Zhonghua Xue Ye Xue Za Zhi. 2011; 32(8): 521-4.

75. Rossi D, Sala L, Minisini R, Fabris C, Falleti E, Cerri M, Burlone ME, Toniutto P, Gaidano G, Pirisi M. Occult hepatitis B virus infection of peripheral blood mononuclear cells among treatment-naive patients with chronic lymphocytic leukemia. Leuk Lymphoma. 2009; 50(4): 604-11. 